\title{
128. 歩道路面の明るさと視線距離に関する一考察
}

\author{
安藤 和彦森 望林 堅太郎 \\ （国土交通省 国土技術政策総合研究所）
}

\section{1.はじめに}

夜間に歩行者や自転車は、どの程度先を見ながら通行しているのかを、試験走路内に設定した仮設 歩道に歩行者及び自転車を通行させ、通行後のヒアリングにより調査したので報告する。

\section{2. 実験概要}

国土技術政策総合研究所内の試験走路に約 $50 \mathrm{~m}$ の仮設 歩道を設置し、設定した照度レベル毎に仮設歩道を被験者 に通常の速度で歩行させ、通過後、歩行中何メートル先を 視認しているかについてヒアリングを行った（以下、被験 者から視認位置までの距離を視線距離という)。仮設歩道で は、表 1 に示す実験条件を設定し、被験者の目の順応状態 を考慮し低い照度レベルから順に通行させた。また周辺環 境は、仮設歩道近傍には道路照明を点灯し、模擬的に歩道 周辺の光環境の有無を設定した。

表 1 実験条件

\begin{tabular}{|c|c|}
\hline 督道㽬员 & $4 \mathrm{~m}$ (第 4 筁第 2 极の道路) \\
\hline 照度設定 & $\begin{array}{l}1.5 / 3 / 5 / 10 / 20(1 \times) \text { ，均斉度 } 0.2 \\
10 / 20(1 x) \text { は周㳄環填有り }\end{array}$ \\
\hline 奵具距是 & 片时列 $(8 \mathrm{~kJ})$ ，高さ $5.2 \mathrm{~m}$ 、取付 $2 n^{\circ} \geqslant 26 \mathrm{~m}$ \\
\hline 光源 & 虽光水銀ランプ HF200X \\
\hline 被钴者 & 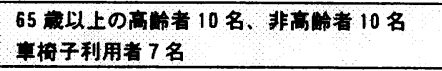 \\
\hline 步道上障害物 & 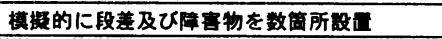 \\
\hline 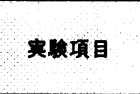 & 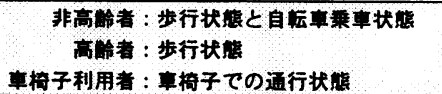 \\
\hline
\end{tabular}

設定した照度レベルは JIS の 4 段階と、諸外国の基準値で最も低く設定されている CIE の $1.5 \mathrm{Lx}$ を合わせ 5 段階とした。非高齢者は歩行状態と自転車乗車状態で、高龄者は歩行状態のみで実験を行 つた。実験では、実際に下肢不自由者で車椅子を利用している被験者についても、照度レベル $1.5 \mathrm{Lx}$ を除く条件で測定した。なお各照度レベルの設定值に対して、実際の照度は土10\%程度の変動があっ た。

\section{3. 実験結果}

図 1 に実験結果を示す。

・照度が高くなるに従って視線距離が延びている。 この傾向は、どの被験者においても同様である。

・非高齢の歩行者は、照度レベル 20Lx で昼間と同程 度の視線距離になっている。高齢者では $20 \mathrm{Lx}$ でも 昼間の視線距離にまでは達しない。

・自転車は、照度レベル $10 \mathrm{Lx}$ 以上になると、昼間よ りも遠方を視認している。

・歩行者等と比べて車椅子利用者の視線距離は短く、 その差は約 10〜 $15 \mathrm{~m}$ 程度であった。

\section{4. 考察とまとめ}

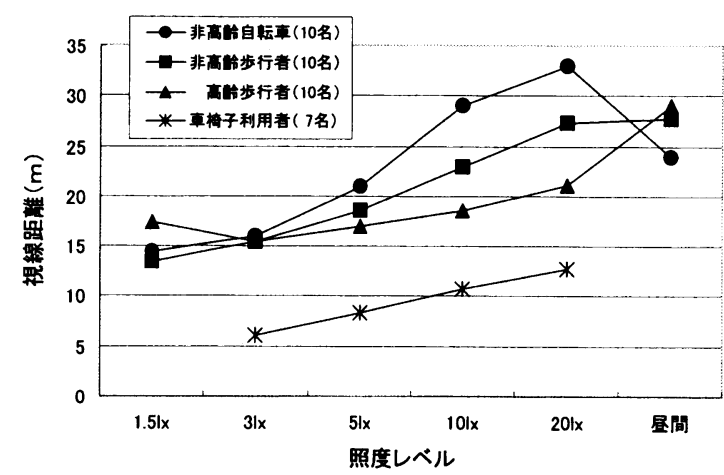

図 1 照度レベルと視線距離の関係

路面の明るさが少なくなると、視認可能範囲が狭くなることでまず足下を気にして視線距離が短く なっている。一方、照度レベルが $20 \mathrm{Lx}$ になると非高齢者であれば昼間と同様の視線距離になってい る。歩行者照明として、どの程度の明るさが必要かは十分議論を要するが、20Lx 程度あれば満足で きるレベルであると判断される。

ただし、高齢者においては今回の実験では視線距離の最大値が明確になっていない。また、自転車、 車椅子利用者については、視線距離が歩行者とは異なるものであることが明らかになつた。周辺の視 認可能範囲、移動速度、移動形態（例えば、車椅子利用者は車輪を廻すたびに前傾姿勢をとる）等が 影響していることが考えられるので、これらについてさらに検討が必要である。

\section{参考文献}

1）日本工業標準調査会審議：JIS Z 9111-1988 道路照明基準 日本規格協会

2) Publication CIE No.136-2000 : "Guide to the lighting of urban areas"

An Experimental Study on Brightness of Sidewalk Surface and Sight Distance Kazuhiko ANDO, Nozomu MORI and Kentaro HAYASHI 